Reviews \& Debates

\title{
HOW USEFUL IS PIKETTY'S ANALYSIS FOR POLITICAL ACTION?
}

\author{
MARJORIE GRIFFIN COHEN \\ Simon Fraser University \\ Piketty, Thomas. 2014. Capital in the Twenty-First Century. Cambridge, MA: \\ The Belknap Press of Harvard University Press. ISBN 13: 9780674430006. \\ Hardcover: 55.95 CAD. Pages: 696.
}

Probably no other progressive economist since J.K. Galbraith has received the attention that Thomas Piketty has from his book Capital in the Twenty-First Century. For example in anticipation of a symposium in Vancouver, Business Vancouver ran a piece with the title "Piketty Mania: Just Don't Throw Your Underwear" (June 23, 2014). He became an economics superstar who created a surge in academic attention to inequality, something usually confined to the research of a small number of under-appreciated, left-wing economists.

Piketty's work is certainly important and I want to stress the ways that it is, but I also want to question the significance of his analysis for political action. This will be examined by looking at the major issues currently confronting global economies and where Piketty stands on these issues. Also examined will be just how significant his approach is to political activism. My main point will be to show that Piketty gives little attention to political activism as a significant force for reducing inequality within capitalism, something that stems from his neglect of its significance in the changing shape of capitalism at crucial points in history.

\section{Importance of Piketty's Work}

Piketty's research puts the distribution of wealth and inequality in Europe and North America at the centre of economic analysis of capitalism. This involved a massive amount of research into the distribution of both income and wealth over a long period of time, information that has not been available previously. In doing this he examines three things: inequality from income, inequality in capital ownership, and the interaction between labour and capital inequality. 
Piketty calls himself a political economist and stresses the deeply political nature of economics, mainly to show that there is no economic determinism regarding inequality. He says this because he recognizes the ability of states to reduce inequality, if they want to, and clearly at times the state has been active in redistribution. But since the 1970s this has changed, specifically because of public policy related to privatization and changes in tax regimes. Almost all wealth is now private with public wealth at about zero. His main "theoretical" point is that a country that saves a lot and grows slowly will over a long time accumulate a huge capital stock (relative to income) that will affect the social structure and distribution of wealth. North America is characterized as consisting of "hypermeritocratic" societies where the initial accumulation occurs through enormous labour inequality (this is corporate managers who have had their "hand in the till"). Europe's wealth structure is typified as consisting largely of "hyperpatrimonial" societies where inheritance is the main driver of wealth accumulation. Both types of accumulation lead to an inegalitarian spiral.

In the earlier parts of the $20^{\text {th }}$ century this inequality was reduced by actions associated with historical events, according to Piketty -- the two great wars and the great depression of the 1930s. So, he sees progressive taxation as being more a product of two world wars than it was of democracy. The disastrous fiscal situations in these cases meant that even those on the political right supported progressive taxes and high marginal tax rates. But also, these three emergency conditions led to government actions of nationalization, rent control, indexed minimum wages, and highly progressive taxes (sometimes confiscatory) on income and inheritance.

\section{Solutions}

Piketty's solutions to inequality fit squarely into a traditionally liberal economic framework. He believes that education and access to technology is a great leveler and the best way to improve labour productivity is to invest in education. Interestingly, he does not see improvements in social mobility through education occurring in the long run. He is also a strong supporter of free trade ("free trade and economic openness are ultimately in everyone's interest”) and globalization. Real gains accrue from both, primarily through economic growth. Piketty sees economic growth as crucial to the reduction of inequality, although the low growth regimes in developed countries anticipated for the future, coupled with no political appetite for egalitarian change, means reductions in inequality are unlikely to occur.

For Piketty, the most important policy tool to reduce inequalities would be a global capital tax, a tax not simply on real estate but on all capital. Because of the huge increases in top managers' remuneration (which they more or less set themselves), Piketty favours a confiscatory marginal tax rate for the very top wealth owners. The 
point of this is not revenue-generating (past the initial stage of the tax), but to change behaviour. He recognizes that only the huge reductions in marginal tax rates have made enormous corporate remuneration packages worthwhile. But altogether Piketty is very pessimistic about the possibility of a tax like this occurring. He asserts it cannot be done by individual nations, and sees little likelihood of international cooperation on high marginal tax rates.

\section{Neglected Issues}

Both the analysis of the rise of inequality and the possibilities for change neglect a very significant aspect of public policy and change. That is the actions of groups and people and the policy issues that affect their activities. Piketty does not, for example, give much weight to how capitalism in rich countries was influenced in the periods from 1920 - 1970 by the actions of people. Piketty is an excellent economic historian and his long-run data are convincing. But he is not really a historian of social or democratic change. While he occasionally gives a nod to trade unions and other activists, the overall treatment of their contributions is weak. It did matter that people fought for minimum wages, unemployment insurance, public health institutions, education, employment standards, and a whole host of social protections. These not only kept people out of poverty, but were also significant for economic stability within capitalism. Neither the state nor corporations were natural allies in these struggles, even though the system in general benefited. The struggles were real, and they were productive.

Also not examined by Piketty are the deliberate low-wage policies by developed nations that coincided with their globalization initiatives. This has accelerated in the last decades of the $20^{\text {th }}$ century and the beginning of the $21^{\text {st }}$. Austerity policies by governments routinely undermine the social and economic gains people had made. The massive increases in available labour through globalization have been the primary motivation for the wage declines. Capital's continual impoverishment of work in poor countries means that increasing quantities of lowwage workers now more easily cross national boundaries without citizenship rights. This is the over-arching context for the downward pressure on social supports and wages, but even more direct actions occur as governments adopt balanced budget policies and undermine labour protections.

Altogether, the solutions section in Capital is not the most important part of the book. The call for progressive taxes can give some support to those groups who recognize the disastrous nature of "austerity" policies, but ultimately Piketty gives very little credence to activism toward changes in the future. The story of inequality relates to the top and the rest. Piketty has given attention to the top, but it's "the rest" that also needs analysis. The top now flourishes because governments relinquished control over capital 
and have been captured by capital. The bottom stagnates because governments consciously do the bidding of capital to control wages.

Piketty does not show that inequality is intrinsically bad for capitalism. That is, it does not negatively affect the working of the system itself and he does not put the primary blame on inequality for increased economic volatility. His main arguments are that inequality is bad because it is unfair and undemocratic. This is true, but the ultimate message - that inequality can continue without disrupting capitalism (unless people revolt), coupled with his lack of optimism about policy to control the inegalitarian spiral, means that this is ultimately a book with analysis, but with few pragmatic ideas. This means that there is still lots to do. Piketty has given great ammunition for doing something about a growing problem for society but these are arguments that will have absolutely no impact on the class that benefits from inequality and that is important, because they are the ones who have the collective ears of governments. My sense is that the analysis now needed relates to the harm inequality does to economic performance as well. 